\title{
PRODUCTION OF BIODIESEL FROM LOCAL AVAILABLE ALGAE IN JORDAN
}

\author{
Nader Aljabarin', Asem Al Jarrah² \\ 1 Natural Resources and Chemical Engineering Department, Tafila Technical University, Tafila, Jordan, e-mail: \\ aljabarin@ttu.edu.jo; asem.aljarrah@yahoo.com
}

Received: 2017.08.30

Accepted: 2017.09.05

Published: 2017.11.01

\begin{abstract}
The present study aims at producing diesel out of algae. The production of biodiesel was performed at Tafila Technical University laboratories. The algae were brought from Almansora stream at Tafila governorate - Jordan and afterwards dried in an oven at $80{ }^{\circ} \mathrm{C}$ for 12 hours. The dried algae were ground using disc mill until powder was obtained. The powdered algae underwent a distillation process with the addition of iron sulphate hydrate to the algae using a distillation column in order to extract the oil. Methanol was added to the oil, which was obtained from the distillation and using potassium hydroxide as a catalyst, the product was then separated in a funnel for about 10 hours until two layers of the solution were obtained; the organic layer represents the biodiesel. The biodiesel attributes are similar to the diesel oil, except that it reduces the emission of carbon dioxide $\mathrm{CO}_{2}$ and there is no emission of sulphur dioxide $\mathrm{SO}_{2}$.
\end{abstract}

Keywords: algae, biodiesel, Almansora, Jordan.

\section{INTRODUCTION}

Algae are a diverse group of aquatic organisms that have the ability to conduct photosynthesis. Certain algae are familiar to most people; for instance, seaweeds (such as kelp or phytoplankton), pond scum or the algal blooms in lakes. However, a vast and varied world of algae exists. They are not only helpful to us, but also critical to our existence. The term "algae" covers many different organisms capable of producing oxygen through photosynthesis. These organisms are not necessarily closely related. However, they share certain common features, which distinguish them from the other major group of photosynthetic organisms, i.e. the land plants.

Algae belong to a large group of simple photosynthetic organisms. They are subdivided into two major categories based on their size. Microalgae, are small free-living microorganisms that can be found in a variety of aquatic habitats. They are able of thriving in freshwater, brackish, marine and hypersaline aquatic environments and have been reported ${ }^{1}$ in desert crust communities, there- by being able to endure temperature extremes and low water availability. Microalgae are easily distinguished from their larger photosynthetic cousins, the macroalgae, which have evolved defined anatomical structures resembling leaves, stems, and roots of higher plants.

Microalgae were among the first life forms on Earth [2]. They are capable of fixing large amounts of carbon dioxide while contributing to approximately $40 \%$ to $50 \%$ of the oxygen in the atmosphere, thus helping to support the majority of life on our planet. Microalgae are highly productive on a global scale, with cell doublings occurring 1-4 times per day. While microalgae make up only $0.2 \%$ of global biomass generated through photosynthesis, they account for approximately $50 \%$ of the total global fixed organic carbon [3]. Microalgae, like terrestrial plants, grow and multiply through photosynthesis, a process whereby light energy is converted into chemical energy by "fixing" atmospheric $\mathrm{CO}_{2}$ through the following reaction:

$$
\mathrm{CO}_{2}+6 \mathrm{H}_{2} \mathrm{O}+\text { Light Energy } \rightarrow \mathrm{C}_{6} \mathrm{H}_{12} \mathrm{O}_{6}+6 \mathrm{O}_{2}
$$


Algae are aquatic, plant-like organisms. They encompass a variety of simple structures, ranging from single-celled phytoplankton floating in the water, to large seaweeds (macroalgae) attached to the ocean floor [4]. Algae can be found anywhere on Earth: residing in oceans, lakes, rivers, ponds and even in snow.

What makes algae only plant-like organisms, instead of full-fledged plants? While algae are often called primitive plants, other terms, like protists, can be used [5]. Protist may be a more accurate term, particularly for the single-celled phytoplankton [8]. However, larger, more complex algae, including kelp and chara, are often mistaken for submerged plants.

The difference between these seaweeds and submerged plants is in their structure. Macroalgae are simpler, and attach themselves to the seabed with a holdfast instead of true roots [4]. Aquatic plants, whether floating, submerged, or emergent (starting in the water and growing out), have specialized parts such as roots, stems and leaves [3]. Most plants also have vascular structures (xylem and phloem), which carry nutrients throughout the plant. While algae contain chlorophyll (like plants), they do not have such specialized structures [7].

As algae can be single-celled, filamentous (string-like) or plant-like, they are often difficult to classify. Most organizations group algae by their primary color (green, red, or brown), though this solution creates even more problems than it solves [4]. The various species of algae are vastly different from each other, not only in pigmentation, but in cellular structure, complexity, and chosen environment $[4,5]$. As such, algal taxonomy is still under debate and some organizations classify algae under different kingdoms, including Plantae, Protozoa and Chromista [8]. While the overarching kingdom classification is not always agreed upon, the species, genus, family, class and phylum of each alga generally are [6].

Primarily, algae are not as highly differentiated in the way that plants are, according to the authors of "Algae: Anatomy, Biochemistry, and Biotechnology, $2^{\text {nd }}$ Ed." [Barsanti L. \& Gualtieri P., 2014]. That is to say, they lack true roots, stems and leaves, as well as a vascular system to circulate water and nutrients throughout their bodies. Second, many algae are unicellular, according to a 2014 article published in the journal Current Biology. They also occur in a variety of forms and sizes. They can exist as single, microscopic cells; they can be macroscopic and multicellular; live in colonies; or take on a leafy appearance as in the case of seaweeds such as giant kelp. Picoplankton are between 0.2 to 2 micrometers in diameter, while the fronds of giant kelp are as large as 60 meters in length. Lastly, algae are found in a range of aquatic habitats, both freshwater and saltwater.

\section{METHOD AND PROCEDURE}

The flow diagram for the production of biodiesel from algae in this work is shown in Figure 1. Appendix A shows photos for the steps of the process. The procedure is as follows:

1. Algae from a stream in Almansora at Tafila governorate have been drained in an oven at $80^{\circ} \mathrm{C}$ for 12 hours.

2. The sample was ground to a powder by using disc mill.

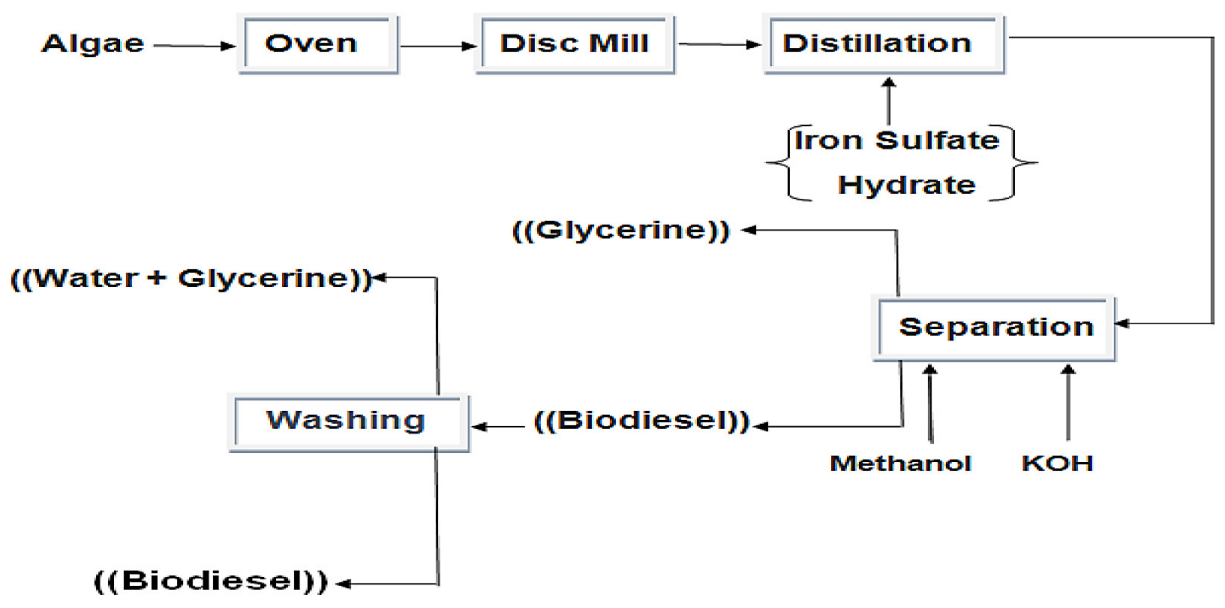

Figure 1. Flow diagram for production of biodiesel from algae 
3. Iron Sulphate Hydrate in the amount of $20 \mathrm{~g}$ was added to $5 \mathrm{~g}$ of algae and distilled water up to $100 \mathrm{ml}$ was added and mixed well.

4. Boiling chips are added to the mixture to distribute the heat and prevent explosion.

5. The mixture was distilled in a distillation column for 2 hours and 90ml Algae oil was obtained.

6. Algae oil in the amount of $25 \mathrm{ml}$ and $10 \mathrm{ml}$ of methanol and potassium hydroxide $\mathrm{KOH}$ ( $(97.5 \%$ methanol, $2.5 \%$ potassium hydroxide $\mathrm{KOH})$ ) were added to a separator funnel and shaken in the separator for 3 minutes. It had to be vented every 30 seconds. The reaction that took place in this step is as follows:

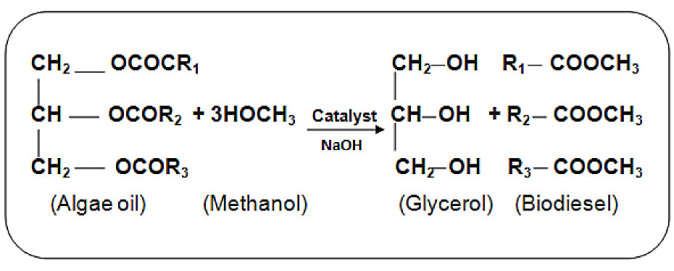

7. The product was left for $8-12$ hours. When two layers were formed, the organic layer, which represents the biodiesel, was collected.

8. The biodiesel sample was tested by taking a small amount of the sample in the spatula and heating it with a lighter, the sample combusted rapidly.

\section{RESULTS AND DISCUSSION}

In the process $90 \mathrm{ml}$ of oil was obtained from 5 grams of algae, and $7 \mathrm{ml}$ of biodiesel was obtained from $25 \mathrm{ml}$ of oil. Therefore, we obtained $7 \mathrm{ml}$ of biodiesel for each $5 \mathrm{~g}$ of algae. A good yield of biodiesel was obtained from algae which suggests that biodiesel from algae can be used efficiently as an alternative source of diesel. Moreover, the advantages of biodiesel from algae oil are as follows:

1. It provides rapid growth rates,

2. Algae biofuel is non-toxic,

3. Algae biofuel is highly bio-degradable,

4. High levels of polyunsaturated in algae biodiesel is suitable for cold weather climates,
5. It can reduce carbon dioxide emissions based on where it is grown,

6. Algae can be cultivated on land, fresh water, or seawater.

On the other hand, there are certain disadvantages of biodiesel from algae:

1. They produces unstable biodiesel with many polyunsaturated fats,

2. Biodiesel performs poorly compared to its mainstream alternative,

3. It is relatively new technology. Other limitations include the low concentrations of free $\mathrm{CO}_{2}$ that are required for peak algal growth and that algal grazers are a significant, but somewhat ignored problem.

\section{CONCLUSIONS}

Biodiesel can be produced from algae. Technically, algae are an economic option for the production of biodiesel, because of the low cost and broad availability. We had found that we can produce biodiesel from Algae, we can use Algae as a source of renewable energy, and many researchers found that algae is the best source for the production of biodiesel, but this subject has not been explored sufficiently. Further research about the presence of algae, calculation of the production of biodiesel fuel ratio, and analysis chemotherapy needs to be conducted.

The cost of energy production from biodiesel produced from algae is approximately ${ }^{8} 8-20$ $\$$ per gallon, pointing out that modern technologies and systems co-production, and food producers, pharmaceuticals, and projects of chemical high-value, make the total cost of production of biofuels from algae project profitable.

The technology of fuel production from algae is still in its infancy; therefore, the production is expensive and the cost is higher than the global sales of fossil fuels price, since the cost of biofuels production is approximately $\$ 10$ per gallon, while the price of diesel per gallon on our markets amounts to $\$ 3.1$.

With the continuous development in technology, the discovery of algae strains better 
Appendix: Steps for producing biodiesel from algae.

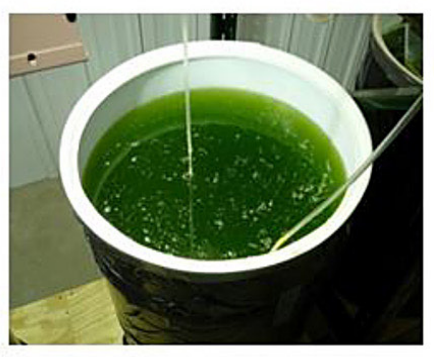

Fig.1: Algae, LG

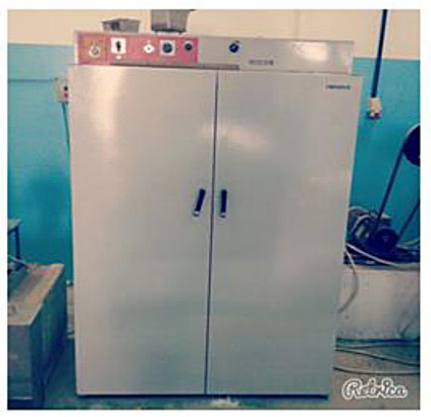

Fig.3: Oven

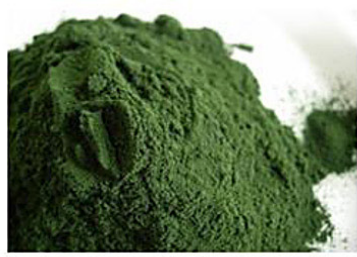

Fig.5: Algae powder

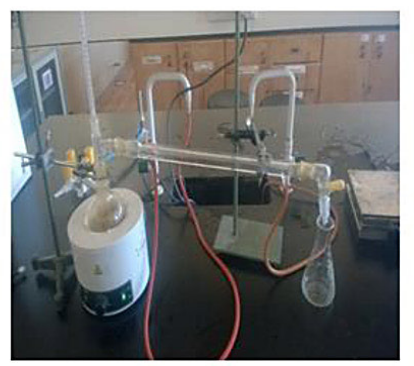

Fig.7: Distillation process

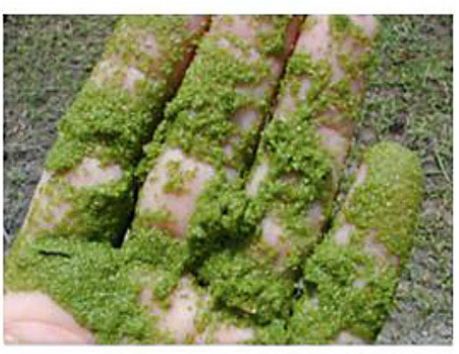

Fig.2: Fresh Algae, LG

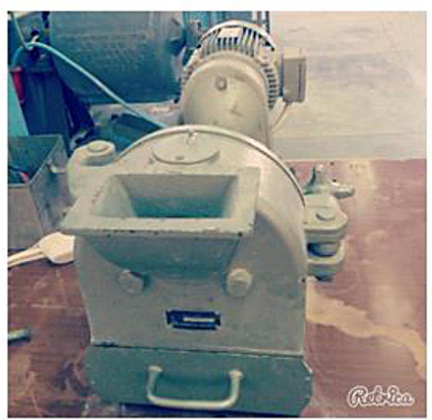

Fig.4: Disk mill

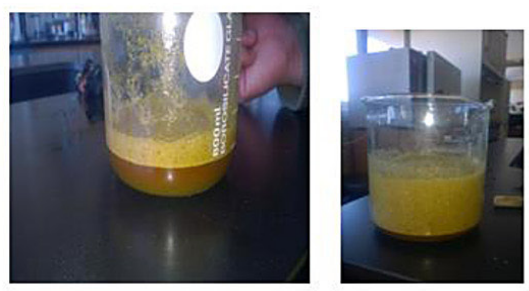

Fig.6: After added $\left(\mathrm{FeSO}_{4} \cdot \mathrm{H}_{2} \mathrm{O}\right)$ to Algae

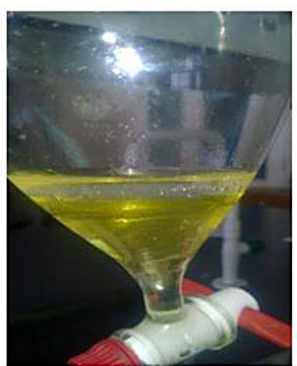

Fig.8: Separation process.

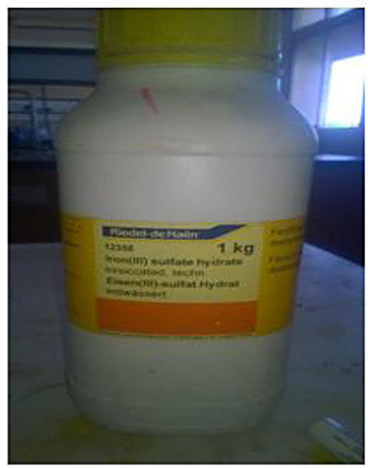

Fig. 9: $\left(\mathrm{FeSO}_{4} \cdot \mathrm{H}_{2} \mathrm{O}\right)$ 
suited for the production of fuel oils, and genetic engineering of the available strains, it will hopefully be possible to reduce the production rate, compared to the continuing rise in the prices of oil derivatives.

\section{REFERENCES}

1. Barsanti L., Gualtieri P., 2014. Algae: Anatomy, Biochemistry, and Biotechnology, $2^{\text {nd }}$ Ed. CRC Press, 2008.

2. Benemann J.R., Pursoff P., Oswald W.J. 1978. Engineering Design and Cost Analysis of a Large Scale Microalgae Biomass System. NTIS \#H CP/ T1605-01 UC-61.Washington, D.C.: U.S. Department of Energy, pp. 91.

3. http://technolabelbahaagp.googoolz.com/t1151-topic.
4. http://www.esru.strath.ac.uk/EandE/Web sites/02-03/biofuels/what_biodiesel.htm.

5. http://www.renewablesinfo.com/drawbacks_and benefits/biofuels_from_algae_advantages_and_ disadvantages.html.

6. Monthly_US_Raw_Material_Usage_for_US_Biodiesel_Production_2007_2009.pdf (application/ pdfObject)" (PDF). assets.nationalrenderers.org. 2010. Retrieved March 23, 2012.

7. Odum H.T. 1971. Environment, Power and Society. Wiley-Interscience. p. 331.

8. Omidvarborna et al. 2014. Characterization of particulate matter emitted from transit buses fueled with B20 in idle modes. Journal of Environmental Chemical Engineering, 2(4), 2335-2342. DOI: 10.1016/j.jece.2014.09.020.

9. Wageningen University \& Research Centre, 2010. Research on Microalgae within Wageningen UR. Wageningen University, Web. 